\title{
Character Education in the Pandemic Era: A Religious Ethical Learning Model through Islamic Education
}

\author{
Nadri Taja*, Encep Syarief Nurdin, Aceng Kosasih, \\ Edi Suresman and Tedi Supriyadi \\ Universitas Pendidikan Indonesia, Bandung-Indonesia \\ https:// orcid.org/0000-0002-5233-9837 \\ https://orcid.org/0000-0002-2759-5046 \\ https://orcid.org/0000-0002-1151-0685 \\ https:// orcid.org/0000-0003-4552-1574 \\ https://orcid.org/0000-0003-0307-1958
}

\begin{abstract}
The social distancing policy in the COVID-19 outbreak has influenced the non-holistic learning process, causing several moral problems. The learning process tends to promote the cognitive aspect, while the affective aspect tends to be neglected. This research aims at offering a learning model that promotes religious ethical values through religious education in junior high schools (SMP/Sekolah Menengah Pertama) in an effort to develop effective attitudes. The development of the model is carried out in five stages of research, namely analysis, design, development, implementation, and evaluation (ADDIE). This research involved two groups of participants consisting of 376 students and 45 Islamic Education (PAI/Pendidikan Agama Islam) teachers in junior high schools in West Java. The research results explore the PAI learning model that develops religious ethical values as learning objectives. The process of internalizing these values is developed through the processes of knowing, of doing, and of being. Religious ethical values that are developed in students are the crystallization of four prophetic characters, namely fathonah, siddiq, amanah, and tabligh. The test results of two junior high schools, both public schools and religious-based schools, concluded that the application of the religious ethical learning model was able to improve students' religious ethical character at a high level. This research contributes to the development of PAI learning designs in the pandemic era based on the development of prophetic characters. In addition, this research can be a guideline for teachers or academics in developing research related to student character within the framework of character education.
\end{abstract}

* Corresponding author: Nadri Taja; Email: nadritaja@upi.edu 
Keywords: ethical-religious; character education; learning model; pandemic; prophetic

\section{Introduction}

The new format of the learning process during COVID-19 pandemic era, namely through a virtual learning system, has raised several problems, such as the issue of students' moral ethics (Baloran, 2020). This has been unsettling among educators regarding the process of character education in students through virtual learning. This concern is motivated by a principle that in addition to transferring knowledge, the educational process also transfers values (Muhtar et al., 2020; Suherman et al., 2019). In online learning at home, teachers place more emphasis on developing cognitive domains. It is challenging for teachers to observe virtuous practices as a part of the learning process because the school serves as an arena for students to practice character (Milliren \& Messer, 2009). Thus, they become unable to carry out their functions. Therefore, efforts are needed to formulate the learning of moral ethics values specifically in the pandemic era so that the learning process can still take place holistically.

It is important to explore the formulation along with the phenomenon of student behavior during the learning process, which tends to lack discipline and responsibility (Intania, 2020) such as playing games during the learning process. This also indicates the lack of respect in students for knowledge and teachers during the learning process (Wardhani, 2018). Moreover, the lack of direct social interaction causes a great deal of deviant behavior (Krings et al., 2021), hence the importance of a learning formulation based on the development of ethical-moral values in the pandemic era. On the other hand, this is a challenge and an opportunity for teachers to create learning innovations in a pandemic situation. The professionalism of a teacher in a pandemic situation continues to be tested.

Research related to education for the moral development of students has attracted the attention of researchers in various countries. Soto-Pérez et al. (2021) analyzed the influence of ethical ideology and students' moral significance on the level of student performance and academic achievement. By using partial least squares path modeling (PLS PM) statistical analysis, the research results reveal that the ideology of justice and deontology can increase moral significance, which also positively increases students' citizenship behaviors, students' in-role performance, as well as academic achievement. In other words, justice, deontology, and moral significance are factors that can improve student academic performance and achievement. Duperon (2018) explored the gap between ethical theory and ethical practice in ethical learning in American colleges. Through the teaching approach of Confucianism, the moral formation must be led by a consistent ethical theory and manifested in prosocial behavior that is focused on self-direction, openness, and the acquisition of skills in line with attention and will. Boonsong et al. (2018) developed learning management devised for the improvement of moral ethics and a student code of ethics at Rajamangala Thanyaburi University of Technology (RMUTT) Thailand. The research results showed that educators can promote a code of ethics and moral ethics for the desired character of the teaching profession through integrated learning techniques consisting of role-playing, service-learning, contract system, value 
clarification, and concept mapping through three steps. The first step is to warm up to understand learning, the second step is to carry out the procedures, namely clarification of values and role-playing for development, and the third step is to conclude and evaluate student learning for mapping their results. Lukviarman et al. (2018) explored the factors influencing a person's commitment to the code of ethics. The results of his research reveal that religious feelings and moral maturity have a positive relationship with commitment to the code of ethics In contrast to these studies, this research is focused on developing a learning model that promotes religious ethical values through Islamic education (PAI) at the junior high school level in a virtual learning platform during the COVID-19 pandemic.

\section{Theoretical Framework}

At the conceptual level, values are realized as 'principles' and fundamental beliefs, which serve as general guidelines for behavior, and as standards for determining whether an action is considered good or desirable (Halstead \& Taylor, 1995, p. 169). In relation to religion, religious values are principles of moral ethical behavior that are constructed by traditions, texts, and religious beliefs. These behaviors include kindness, obedience, submission to God, self-discipline, boldness, trust, generosity, respect for one's religious symbols and leaders, obedience to religious instructions, and openness to correction when someone makes a mistake (Saluun \& Timin, 2020). Ethical studies are necessary to explore behaviors relevant to human traits (Bertens, 1993; Auweele, 2015). In the modern world, an ethical theory is associated with the issue of goodness and truth (Graham, 2011), and God's commandments (Copp, 2006). In other words, ethics are relevant when they are associated with religion. Since religion has become the key characteristic of human life as homo-religious (Albright \& Ashbrook, 2001), religion has also become one of the most powerful forces in guiding one's actions (Fridayanti, 2015), even as an important social power that has a strong influence on the social environment (Emmons \& Paloutzian, 2003). Therefore, religion is significant in human daily life (Lewis \& Cruise, 2006). This emphasizes that religion and morals cannot be separated (Albulescu, 2019), and these become an important part in the moral education process (Suleymanova, 2020; Yusupova, 2020).

In relation to ethics and religion, Izutsu (2006) introduced them with the term 'religious ethics', which are interpreted as moral principles to guide humans in behaving ethically in accordance with the world view of religion (Abdurrahman, 2005). By analyzing the main source of Islam, namely the Qur'an, ethics were classified by Izutsu (2006) into three different criteria, namely criteria that show and describe the nature of divinity, criteria that describe aspects of the fundamental attitude of human relations to God, and criteria that describe the principles and rules of normative life in an Islamic society. The first category was developed into theories about the attributes of God or the Divine Ethics by theologians. The second and third criteria are referred to as religious ethics (Izutsu, 2006).

For a Muslim, the perfection derived from the practice of religious ethics is embodied in the figure of the Prophet Muhammad PBUH (Ali, 2015; Katz, 2010). Among Muslims, the Prophet Muhammad PBUH became an example for his 
followers in all forms of words, deeds, and behavior of the prophet in building relationships with God and humans. Muslims always strive to be what was practiced and taught by the Prophet (Khānn, 2009; Schoeler, 2010). The practice of religious ethics is reflected in the four main characteristics of a prophet, namely intelligence (Fathonah), honesty (Siddiq), trustworthy (Amanah), and fluency in conveying God's message so that it is easily accepted (Tabligh) (Burge, 2020; Khāan, 2009). These four characteristics are the crystallization of the practice of religious ethics.

The terms of morality or ethics or character relate to the question of values. Solving value problems can only be done through value education because values are the core of education both in theory and in practical activities (Halstead \& Taylor, 1995). Therefore, value education has a vital role in solving the value problems that arise among students. Education is not only understood as a form of knowledge but a part of life based on ethical values (Ryan et al., 1999). Cultivating and developing character values must involve methods, techniques, and materials so that the goals of character education are achieved (Licona, 1991). In other words, a learning model is required to attain the goal of character values (Metzler, 2017; Wortham, 2006; Yun-fei, 2004).

The learning model is a conceptual framework describing a systematic procedure for managing learning experiences to attain certain learning objectives, and assists as a guide for learner designers and teachers in planning and implementing learning activities (Joyce et al., 2009; Rusman, 2011; Tayeb, 2017). The necessity of a learning model within the context of developing religious ethical values is a real manifestation in achieving the goals of character education and in designing a character learning model, in which at least four components are needed, namely an Instructional Objective, Entering Behavior, Instructional Procedures and Performance Assessment (Glasser, 1999; Rusman, 2011). Moral education, ethics, or character education has long been the concern of public schools (Figley, 1984; Mouratidou et al., 2007).

\section{Methodology}

\subsection{Design}

To achieve the research objectives in developing a learning model for religious ethics, the ADDIE steps were used as a development research design (Branch, 2009; Cheung, 2016; Gagne et al., 2005; Hsu et al., 2014). In addition, the ADDIE model has been widely used by several researchers in pedagogic development (Lafleur et al., 2021; Oh et al., 2021; J. Yu \& Jee, 2021; S.-J. Yu et al., 2021). ADDIE is an acronym that describes the five steps of development, namely analysis, design, development, implementation, and evaluation (Branch, 2009; Gagne et al., 2005). The design of the development of religious ethical learning was conducted in sequence from the analysis phase to the evaluation phase. The recommendations made during the evaluation phase are to advise future revisions of other phases.

\subsection{Research Procedure}

\subsubsection{Analysis Phase}

This phase describes the needs related to the religious ethics learning model through PAI subjects. This phase comprises two analytical activities, namely the 
empirical conditions of religious ethic learning analysis and literature analysis. In analyzing the empirical conditions of PAI learning during the pandemic, two forms of questionnaires, namely questionnaires to teachers and questionnaires to students, were distributed. The questionnaire to teachers consisted of 10 openended questions. The substance of the questions focused on three aspects, namely learning, psychology, and social while the questionnaire to students consisted of 15 open-ended questions to explore information related to religious insights and attitudes as well as their assessment of the PAI learning process during the pandemic. The questionnaires were distributed to PAI teachers in junior high school using Google Forms. The results were followed up in the form of interviews and documentation studies on learning media.

In the second activity, a literature analysis was conducted by tracing a number of relevant articles in Scopus indexed journals in 2016-2020. The search was carried out using the Publish or Perish application (Supriyadi et al., 2020) by inputting three keywords, namely ethic, religious, and education. The results delivered 268 bibliographies consisting of articles, proceedings, reviews, and book chapters. Furthermore, the results were filtered by setting four criteria to be analyzed. First, the selected bibliography concerned the type of articles, producing a total of 203 articles. Second, the series of titles contained two words, namely ethical and religious. This search was carried out to focus on the research topic. In this second stage, 20 articles were analyzed and then inputted into the reference manager for the import process on the N-VIVO 12 application for coding. A systematic literature review was conducted to explore what universal values were promoted in shaping religious ethical behavior. Afterwards, these values were linked to the theory of religious ethics in the Qur'an to focus on an Islamic perspective (Izutsu, 2006).

\subsubsection{Design Phase}

The design phase aimed at formulating the learning products designs based on the needs in the previous stage. At this stage, the focus was on setting learning objectives, applying approaches, learning scenarios, designing learning materials, and selecting evaluation formats. The initial product was in the form of a design model or conceptual religious ethic learning method. This became an instruction in the next development process.

\subsubsection{Development Phase}

This phase was intended to realize the previous conceptual model design into a product that was ready to be implemented. The products of this stage were in the form of learning plan documents, learning material modules, and learning media used which have obtained expert judgment. Furthermore, the validity test was carried out to evaluate the product validity level based on the assessment of several validators.

\subsubsection{Implementation Phase}

This phase can be divided into two main parts, namely a practicality test, and an effectiveness test. The practicality test was conducted by examining the teachers' responses to the questionnaire relating to product development. The effectiveness test of the product of the religious ethical learning model was carried out to 
determine the increase in students' religious attitudes after participating in the learning process.

\subsubsection{Evaluation Phase}

At this phase, the researchers examined information from users to understand the advantages and disadvantages of the product and obtained user suggestions as feedback from product users.

\subsection{Participants and Research Site}

In selecting the participants, a purposive sampling technique was used by distributing questionnaires with short answers via Google Forms. The questionnaire was distributed through research partners who had access to PAI teachers in junior high schools in the city of Bandung. They distributed the questionnaires to several WhatsApp groups in the SMP PAI teacher forums. The questionnaire relates to the willingness of teachers to be involved in this research project. In the questionnaire the purpose of this study and the extent of the involvement of teachers in this study were explained. The teachers were asked to read and understand the implications of their consent before they indicated their willingness to participate in this research. A number of 45 Islamic Religious Education (PAI) teachers expressed their willingness to be involved in the research. Furthermore, questionnaires were distributed to students through 45 PAI teachers. In this way, 376 junior high school students expressed their willingness to be involved as well. In addition, this research also involved a group of experts consisting of three professors with different spheres of expertise, namely the experts in Islamic religious education, character education, and learning models. The implementation phase of the product was conducted in two junior high schools in Bandung City, West Java, Indonesia.

\subsection{Data Collection and Data Analysis}

Data collection and analysis were carried out in several ways at each phase in this ADDIE model, except in the design phase or the second phase. In the design phase, the research instruments were not used because this phase contains research activities to design product development based on the results of the previous stage. The description of data collection and analysis can be described in a matrix as follows:

Table 1. Matrix of data collection and analysis

\begin{tabular}{llllll}
\hline \multirow{2}{*}{ Phase } & \multicolumn{2}{c}{ Data Collection } & \multicolumn{2}{c}{ Data Analysis } \\
\cline { 2 - 5 } & Technique & Instrument & Product & Approach & Application \\
\hline Analysis & 1. Observation & 1. Observation & 1. Field Notes & Qualitative & Google Doc. \\
& 2. Interview & Sheet & 2. Interview Data & with Coding & NVIVO 12 \\
& 3. Open-Ended & 2. Interview Guide & 3. Student & & Plus \\
& Survey & 3. Student & Responses & & \\
& 4. Focus Group & Questionnaire & 4. Teacher & & \\
& Discussion & 4. Teacher & Responses & & \\
& & Questionnaire & 5. Teachers' Notes & & \\
Design & & 5. Field Notes & & & SPSS IBM \\
Development & Validating & Expert & Expert Assessment & Quantitative & SPsion 26
\end{tabular}




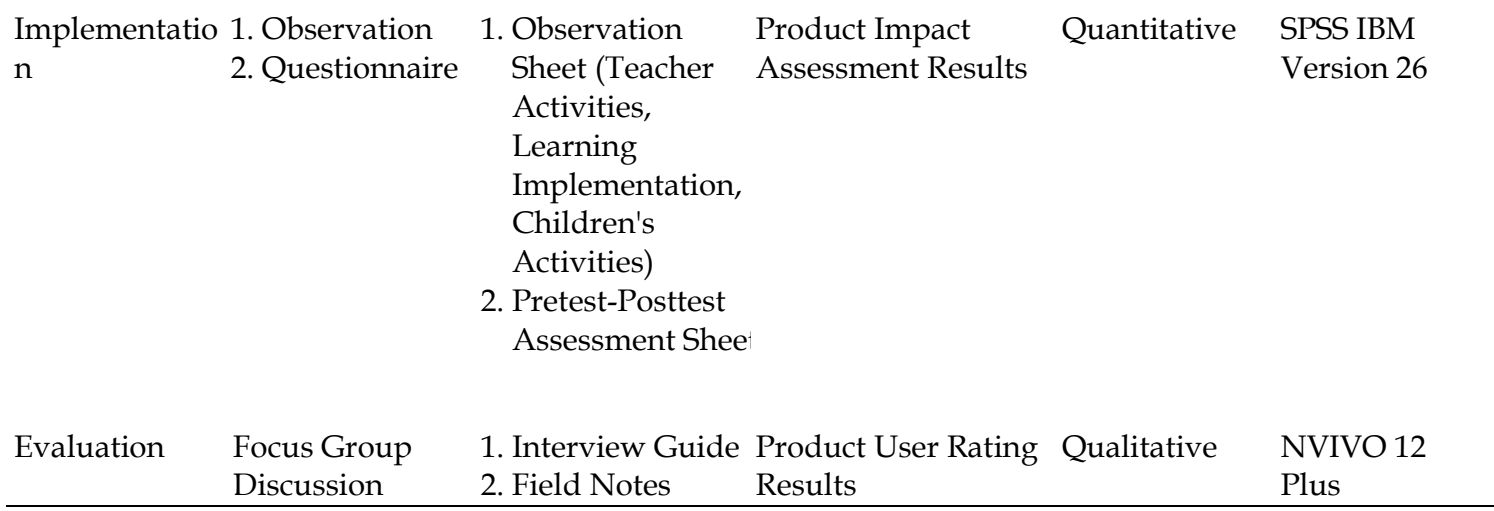

\section{Result}

\subsection{Analysis Phase: The Need for a Religious Ethical Value Learning Model}

\subsubsection{Empirical Conditions for PAI Learning}

The data obtained from the questionnaires filled out by 376 students and by 45 PAI teachers at junior high schools in Bandung City was analyzed. In addition, transcripts of interviews with 12 PAI teachers and observations of learning device documents with data processing through NVIVO12 Plus were also analyzed. The results obtained three findings as to the main themes that describe the empirical conditions of PAI learning in the Bandung City during the pandemic. These themes relate to teacher motivation, instructional strategies, and value problems. Visually, the result of data processing at this phase is presented in Figure 1:

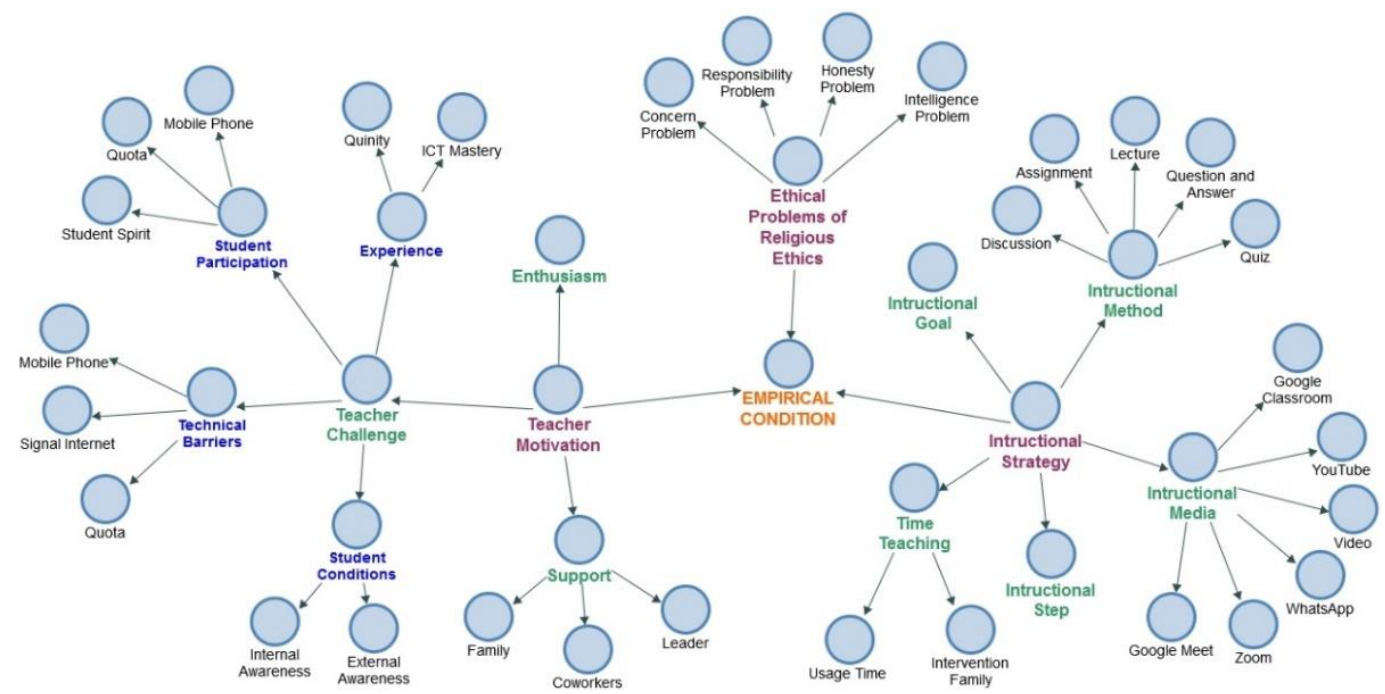

Figure 1. Concept map of empirical conditions for PAI learning

\subsubsection{Teacher Motivation}

The implementation of learning during the pandemic has had an impact on fluctuations in teacher motivation in teaching. During this pandemic, it was essential that teachers maintained high levels of motivation during virtual learning at home. There were two aspects affecting the motivation of PAI teachers in Bandung City in carrying out learning during the pandemic, namely the encouragement of the teacher in running online learning and the teacher enthusiasm. Teachers were less enthusiastic in dealing with virtual learning 
systems compared to face-to-face learning. The lack of teacher enthusiasm was due to the difficulty of interacting directly or physically with students as teachers could not measure students' understanding during online learning. This lack of physical interaction eventually led to a decrease in teaching enthusiasm (Strunc, 2020). This opinion was expressed by 13 teachers. One of the teacher's opinions that represent the teachers' general opinions was as follows:

"It is undeniable that the lack of direct face-to-face has an impact on the decline of teacher motivation in teaching. However, I still have to carry out the teaching obligation." (Teacher 25)

The decline in the teaching motivation of PAI teachers in Bandung City was closely related to the challenges faced by teachers in virtual teaching. The teachers' technological experience in a virtual environment was one of the challenges that determined the efficient running of learning activities (Conrad \& Donaldson, 2011; Ko \& Rossen, 2017). PAI teachers in Bandung City did not have much experience related to virtual learning except during the COVID-19 pandemic. This lack also applied to mastering ICT that supported the implementation of online learning. In addition, technical barriers often faced by teachers were Internet signals, quotas, and learning support devices such as mobile phones as a means of realizing effective communication between teachers and students in the online learning process (Alawamleh et al., 2020; Wong et al., 2021). These factors are considered to affect teacher motivation in teaching. Realizing effective online learning required paying attention to aspects of communication so that the message conveyed by the teaching materials could be communicated effectively (McClain, 2002; Wong et al., 2021). One of the factors that support the establishment of effective communication between teachers and students was the communication media (Alim et al., 2019; Supriyadi et al., 2019). In addition to these experiences and technical barriers, the lack of student participation in the learning process was a challenge for PAI teachers in online learning. Signal factors and means of communication had a negative impact on students' enthusiasm when participating in PAI learning.

\subsubsection{Instructional Strategy}

An instructional strategy is a series of instructional components implemented in instructional activities to achieve instructional goals (Baturay, 2008; Dijkstra et al., 2013). In carrying out the learning process, several instructional components found in this study are related to learning media, learning methods, and teaching time.

The learning media are intended to help students to understand the lesson material (Abdo \& Semela, 2010), which is expected to encourage students' interest and motivation to learn by providing different learning experiences (Aini, 2013). The media most often used by PAI teachers in online learning were learning videos made simply through cellphone recordings, self-made learning videos, or learning videos downloaded via YouTube. In addition to videos, teachers also used Whats App, Google Forms, Google Classroom, and Zoom as media to deliver the material. The teachers sent the links to the lesson material, either the Google Forms link, the YouTube link, or the Zoom link via WhatsApp on the parents' cellphones. This medium is also dependent on the parents' use of their cellphones because there are still many students at the junior high school level who do not 
have their own cellphones to use as learning medium. The result was low student participation in PAI learning.

Furthermore, the method used by the teacher was a lecture or question and answer session via Zoom or Google Meet. However, owing to frequent signal interference and the conditions of online classrooms that are not conducive for learning, using fast and easy learning methods became an issue. Hence, the teacher used alternatives such as offline assignments and quizzes with a predetermined time limit to evaluate the students' level of understanding of the material provided. In addition, in online learning, teachers were required to be able to use limited time. This undeniably affected the learning speed, learning objectives, and learning assessment. The learning duration that was usually used by teachers in one meeting before the pandemic was one and a half to two hours. However, during the period of studying from home (SFH), the learning duration was shorter owing to parental intervention in the use of media, and the limited use of application time due to limited use of Zoom's free license that was only up to 40 minutes. For these reasons the teacher only conveyed the important points of the lesson material to students. When students carried out tasks or conducted question-and-answer sessions with the teacher, it was difficult for the teacher to evaluate whether the answers were the result of students' understanding. Most parents helped their children by providing answers so that they could answer the questions more quickly. This happened because the parents needed their cellphones so they wanted their children to complete the tasks quickly.

\subsubsection{The Problem of Ethic Religious Values}

The implications of the lack of teacher motivation and the implementation of the teachers' instructional strategies affected the problem of achieving the minimum goal of organizing religious education, namely the development of the students' ability to understand, appreciate, and practice religious values as stated in Government Regulation No. 55 of 2007 (Government Regulation, 2007). There were indications that the problems related to achieving the goals of religious education led to religious ethical-moral problems. There are four religious ethical problems in this research, namely i) Intelligence problems included self-closing behavior or refusing to accept suggestions, self-superiority, lack of solutions and minimal academic achievement as problems of intellectual intelligence as well as the tendency of interest in engaging in conflicts such as brawls as a problem of emotional intelligence; ii). Responsibility problems included lack of time discipline, neglect of teacher duties, and neglect in carrying out worship; iii). Honesty problems included academic cheating, tend to be tendentious, and often looking for justification; and iv). Concern problems include lack of respect for teachers during learning, lack of pro-activeness, lack of communicative and individual tendencies. There were 17 teachers who expressed these opinions.

\subsection{2. $\quad$ Model Needs in PAI Learning}

According to Izutsu (2006), religious ethics include the relationship between humans and God, the principles and rules of normative life in Islamic society, and the figure of the Prophet as a manifestation of the perfection of religious ethical behavior (Ali, 2015; Katz, 2010). This is reflected in the four characteristics of the Prophet, namely intelligence (Fathonah), honesty (Siddiq), trustworthy (Amanah), and fluency in conveying God's message so that it is easily accepted (Tabligh) 
(Burge, 2020; Khāann, 2009). People are required to imitate these traits (Katz, 2010; Schoeler, 2010). Thus, religious ethical values that will be developed within the framework of PAI Learning encompass these traits. The four characteristics of the Prophet were developed in several character values, namely fathonah, including intelligence, knowledge, solution thinking, wisdom and realistic; siddiq, including being honest, transparent, loyal, open, and objective; amanah, including responsibility, ability to carry out tasks, keeping promises, upholding principles and honor; and tabligh, including being exemplary and communicative, displaying leadership, and being pro-active and cooperative (Basri et al., 2020; Budiyono et al., 2019; Sultoni et al., 2020; Yasin, 2020). It is essential that these values are internalized by students through the PAI courses. Internalization is an effort to present values, understand values, feel values and embody these values in one's behavior (Hakam, 2010). The effort to internalize these values requires a learning model (Licona, 1991), which is known as the internalization model of religious ethical values. Therefore, the next phase is to design a learning design model for internalizing religious ethical values in PAI subjects.

\subsection{Design Phase: Conceptual Design of Religious Ethical Values Learning Model}

In designing the learning model for religious ethical values, the learning development model proposed by Glasser was adopted. This model consists of four components, namely objective instruction, entering behavior, instructional procedures, and performance assessment (Glasser, 1999; Rusman, 2011). In the instructional goal, the objective system students are focused on practicing ethical religious values permanently as learning objectives presented in the lesson material of the Beliefs in the Prophets. In this case, the Prophets are personal role models (uswatun hasanah) with perfect characters. In entering behavior, also known as the input system, the focus is on instilling religious ethical values extracted from the characteristics of the Prophets, namely Siddiq, Amanah, Tabligh, and Fathonah. In instructional procedures (system operators), the learning steps are developed to promote religious ethical values. The learning steps consist of three actionable steps: First, preliminary activities include apperception, motivation, and explanation. Second, core activities comprise the process of knowing and the process of doing. Finally, the third, a closing activity as an evaluation or being process is the fourth component of Glasser's model, namely performance assessment (output monitor).

Table 2. Syntax of religious ethical model

\begin{tabular}{ll}
\hline \multicolumn{1}{c}{ Activity } & Teacher Behavior \\
\hline Phase - 1 & 1. Greeting to open learning activities and start learning by \\
Introduction & praying \\
& 2. Relating the current lesson to the previous lesson \\
& 3. Motivating students with exemplary stories \\
& 4. Posing questions to students to find out the prerequisite \\
concepts that have been mastered by students & 5. Explaining the learning objectives associated with \\
& religious ethical values. \\
\hline Phase - 2 & 1. Teachers presented video examples of moral problems \\
Exploration (Knowing) & during a pandemic through the Zoom application. \\
& 2. Teachers asked students to observe and take an inventory \\
\hline
\end{tabular}


of the moral problems in the video and then analyze the effects of these problems.

3. Teachers asked students to explain the behavior that should be shown and its effect as an alternative to moral problems in the video.

4. Teachers provided reinforcement to the student's explanation by connecting to the material of faith in the Prophet.

Phase - 3

Review understanding and provide feedback (Doing)

1. Teachers distributed Student Worksheets (LKPD - Lembar Kerja Peserta Didik) containing the basics of the need to imitate the characteristics of the Prophet by presenting absolute values based on the sources of Islamic teachings, namely the Qur'an and Hadith, and reported them in accordance with the directions related to how to work and assignment submission deadline.

2. Teachers asked students to give the Prophet's example as a manifestation of religious ethical values.

3. Teachers asked students to formulate how to apply these religious ethical values in the context of everyday life.

4. Teachers asked other students to respond to the results of the formulation.

5. Teachers provided direction and encouragement for students to practice values and reports related to the results of their experience of practicing these values.

Phase - 4

Reflection (Being)
1. Teachers confirmed the Islamic values contained in the general lesson material by mentioning the arguments in the Al-Quran and Hadith.

2. Teachers and students reflected on Islamic values contained in learning as an internalization effort.

The product of the design model consisted of a blueprint in the form of a draft of learning modules, lesson plans, and evaluation instruments. These products were developed at a further stage by asking experts to review and test their validity and reliability.

\subsection{Development Phase: Development of Learning Model of Religious Ethical Values}

There were two steps in developing the ethical religious learning model. First, three experts were asked to review the resulting product. Second, after experts had assessed the products, the validity and reliability tests of the product were conducted on non-sample students. The results of the experts' assessment using the Likert scale are shown in the following table:

Table 3. Validation results from experts

\begin{tabular}{lcccc}
\hline Assessment component & Expert 1 & $\begin{array}{c}\text { Expert } \\
2\end{array}$ & $\begin{array}{c}\text { Expert } \\
3\end{array}$ & $\begin{array}{c}\text { Averag } \\
\mathrm{e}\end{array}$ \\
\hline Learning module elements & 4.75 & 5.00 & 4.75 & 4.83 \\
Lesson plan & 4.83 & 5.00 & 4.67 & 4.83 \\
Learning evaluation guidelines & 4.67 & 4.67 & 4.75 & 4.70 \\
Learning model syntax & 5.00 & 5.00 & 5.00 & 5.00 \\
\hline
\end{tabular}


Based on the recapitulation table of the learning model by the experts, the result showed that the overall average validation result for the assessment of all learning model products was above 4.5, indicating that the validation of the expert assessment included very good criteria. In other words, the design of the model was appropriate for use in the learning process. Furthermore, the validity and reliability tests of the instruments were conducted to strengthen the judgment. These tests included three steps: i) The researchers compiled 20 statement items that were tested for validity and reliability; ii) this test was conducted in nonsample classes; and iii) after collecting the data, the researchers calculated the results of the validation. The tests results are presented in Table 4.

Table 4. Indicator validation of Siddiq

\begin{tabular}{|c|l|l|l|l|}
\hline Indicator & \multicolumn{1}{|c|}{ Sub-Indicator } & \multicolumn{1}{|c|}{ Value } & Average & Criteria \\
\hline \multirow{5}{*}{ Siddiq } & Honest & 0.5011 & & \\
\cline { 2 - 3 } & Transparent & 0.4895 & \multirow{4}{*}{0.5559} & \multirow{3}{*}{ Moderate } \\
\cline { 2 - 3 } & Loyal & 0.6152 & & \\
\cline { 2 - 3 } & Open & 0.4491 & & \\
\cline { 2 - 3 } & Objective & 0.7248 & & \\
\hline
\end{tabular}

In the indicator of siddiq, the validation value obtained by the honest sub-indicator was 0.5011 , the transparent sub-indicator was 0.4895 , the loyal sub-indicator was 0.6152 , the open sub-indicator was 0.4491 , and the objective sub-indicator was 0.7248 . Based on the five sub-indicators, the average validation value was 0.5559 with moderate criteria.

Table 5. Indicator validation of Amanah

\begin{tabular}{|l|l|l|l|l|}
\hline Indicator & \multicolumn{1}{|c|}{ Sub-Indicator } & \multicolumn{1}{|c|}{ Value } & Average & Criteria \\
\hline \multirow{4}{*}{ Amanah } & Responsibility & 0.7934 & & \\
\cline { 2 - 3 } & Carrying Out Tasks & 0.7476 & \multirow{3}{*}{0.6596} & \multirow{2}{*}{ High } \\
\cline { 2 - 3 } & Keeping Promises & 0.5207 & & \\
\cline { 2 - 3 } & Keeping Principle & 0.7154 & & \\
\cline { 2 - 3 } & Responsibility & 0.7934 & & \\
\hline
\end{tabular}

In the indicator of amanah, the validation value obtained by the responsibility subindicator was 0.7934 , the carrying out tasks sub-indicator was 0.7476 , the keeping promises sub-indicator was 0.5207 , the keeping principle sub-indicator was 0.7154 , and the responsibility sub-indicator was 0.7934 . Based on the five subindicators, the average validation value was 0.6596 with high criteria.

Table 6. Indicator validation of Fathonah

\begin{tabular}{|l|l|l|l|l|}
\hline Indicator & \multicolumn{1}{|c|}{ Sub-Indicator } & \multicolumn{1}{|c|}{ Value } & Average & Criteria \\
\hline \multirow{4}{*}{ Fathonah } & Intelligence & 0.5075 & & \\
\cline { 2 - 3 } & Solution & 0.7889 & \multirow{4}{*}{0.6507} & \multirow{2}{*}{ High } \\
\cline { 2 - 3 } & Knowledgeable & 0.5216 & & \\
\cline { 2 - 3 } & Wisdom & 0.8005 & & \\
\cline { 2 - 3 } & Realistic & 0.6353 & & \\
\hline
\end{tabular}

In the indicator of fathonah, the validation value obtained by the intelligence subindicator was 0.5075, the solution tasks sub-indicator was 0.7889, the knowledgeable sub-indicator was 0.5216 , the wisdom sub-indicator was 0.8005 , and the realistic sub-indicator was0.6353. Based on the five sub-indicators, the average 
Table 7. Indicator validation of Tabligh

\begin{tabular}{|l|l|l|l|l|}
\hline Indicator & \multicolumn{1}{|c|}{ Sub Indicator } & \multicolumn{1}{|c|}{ Value } & Average & Criteria \\
\hline \multirow{4}{*}{ Tabligh } & Example & 0.5974 & & \\
\cline { 2 - 3 } & Communication & 0.5113 & \multirow{4}{*}{0.6163} & \multirow{3}{*}{ High } \\
\cline { 2 - 3 } & Leadership & 0.5808 & & \\
\cline { 2 - 3 } & Proactive & 0.7759 & & \\
\cline { 2 - 3 } & Cooperation & 0.5009 & \\
\hline
\end{tabular}

In the indicator of tabligh, the validation value obtained by the example subindicator was 0,5974, the communication tasks sub-indicator was 0.5113 , the leadership sub-indicator was 0.5808 , the proactive sub-indicator was 0.5808 , and the cooperation sub-indicator was 0.5009. Based on the five sub-indicators, the average validation value was 0.6163 with high criteria.

The shiddiq indicator obtained an average validation of 0.5559 with medium criteria, the amanah indicator obtained an average validation of 0.6596 with high criteria, the fathonah indicator obtained an average validation of 0.6507 with high criteria, and the tabligh indicator obtained an average validation is 0.6163 with high criteria. Therefore, the reliability of the four indicators is concluded to be high with a score of 0.81 .

\subsection{Implementation Phase: Religious Ethical Value Learning Model}

To determine the level of students' religious character, the researchers conducted a limited test in the form of a questionnaire containing 20 statement items. These consisted of five statement items for the siddiq character, five statement items for the amanah character, five items for the fathonah character, and five items for the tabligh character. This questionnaire was distributed to students before being given treatment (pretest) and distributed to students after being given treatment (posttest). The test was conducted on 66 eighth-grade students SMPN PGII 2 Bandung and 63 eighth-grade students of SMPN 40 Bandung. The following is a general description of the students' overall religious questionnaire:

Table 8. Model test results

\begin{tabular}{|c|c|c|c|c|}
\hline School Name & \multicolumn{2}{|c|}{ Type of Classes } & Average (\%) & Interpretation \\
\hline \multirow{4}{*}{$\begin{array}{l}\text { SMP PGII } 2 \\
\text { Bandung }\end{array}$} & \multirow[t]{2}{*}{ Control Class } & Pretest & 63.94 & Moderate \\
\hline & & Posttest & 67.47 & Moderate \\
\hline & \multirow{2}{*}{$\begin{array}{l}\text { Experimental } \\
\text { Class }\end{array}$} & Pretest & 63.76 & Moderate \\
\hline & & Posttest & 80.09 & High \\
\hline \multirow{4}{*}{$\begin{array}{l}\text { SMPN } 40 \\
\text { Bandung }\end{array}$} & \multirow[t]{2}{*}{ Control Class } & Pretest & 51.42 & Low \\
\hline & & Posttest & 53.52 & Moderate \\
\hline & \multirow{2}{*}{$\begin{array}{l}\text { Experimental } \\
\text { Class }\end{array}$} & Pretest & 51.88 & Moderate \\
\hline & & Posttest & 67.91 & High \\
\hline
\end{tabular}

Table 8 shows that before conducting the model test, the level of religious character of students in SMP PGII 2 showed a moderate level. Meanwhile, before conducting the model test, the level of religious character of students in SMPN 40 Bandung showed a low level. After testing the model for internalizing religious ethical values to develop students' religious character, the following results were obtained:

1. The control class of SMP PGII 2 Bandung showed a moderate level, and the experimental class showed a high level. 
2. The control class of SMPN 40 Bandung showed a moderate level, and the experimental class showed a high level.

Furthermore, to determine the significant average difference between the pretest and posttest scores, the average difference test was conducted using a t-test with the assistance of IBM SPSS Version 26. For the test criteria, if the value of Sig. (2tailed) $>a$, then $\mathrm{H}_{0}$ was accepted. Otherwise, if the value of Sig. (2-tailed) $<a$, then $\mathrm{H}_{0}$ was rejected. The t-test results in the control class and the experimental class at SMPN 40 Bandung and SMP PGII Bandung are presented in Table 9. In addition, the proposed $\mathrm{HO}$ is: There is significant difference in the result of the pretest control class and pretest experimental class.

Table 9. The $t$ test results at SMPN 40 Bandung

Paired samples test

\begin{tabular}{ll|r} 
& & Sig. (2-tailed) \\
\hline Pair 1 & Pretest Control Class - Posttest Control Class & .129 \\
\hline Pair 2 & $\begin{array}{l}\text { Pretest Experimental Class - Posttest Experimental } \\
\text { Class }\end{array}$ & .000 \\
\hline
\end{tabular}

The test results show that the value of Sig. (2-tailed) > a was 0.129, then H0 was accepted. In other words, there was no significant difference in the average pretest and posttest scores in the control class. For the experimental class, since the value of Sig. (2-tailed) $<$ a was $0.000, \mathrm{H}_{0}$ was rejected. In other words, there was a significant difference in the average pretest and posttest scores in the experimental class. The results of the t-test at SMP PGII 2 Bandung are presented in Table 10:

Table 10. The $t$ test results at SMP PGII 2 Bandung

\begin{tabular}{llr} 
& \multicolumn{2}{c}{ Paired samples test } \\
\hline Pair 1 & Pretest Control Class - Posttest Control Class & Sig. (2-tailed) \\
\hline Pair 2 & $\begin{array}{l}\text { Pretest Experimental Class - Posttest Experimental } \\
\text { Class }\end{array}$ & .974 \\
\hline
\end{tabular}

The test results show that the value of Sig. (2-tailed) > a was 0.974 , then $\mathrm{H}_{0}$ was accepted. In other words, there was no significant difference in the average pretest and posttest scores in the control class. For the experimental class, since the value of Sig. (2-tailed) < a, was $0.002, \mathrm{H}_{0}$ was rejected. In other words, there was a significant difference in the average pretest and posttest scores in the experimental class.

\subsection{Evaluation Phase: Evaluation of Religious Ethics Value Learning Model} At this phase, PAI teachers were requested to provide feedback regarding the application of the religious ethical model. To obtain this feedback, semi-structured interviews were conducted with four teachers who were the sample in this research. Three questions were asked regarding learning objectives, syntax, and instructional impact in religious ethical learning models. The results of the interview show that from the perspective of the user teachers, the learning objectives were more oriented towards value practice, which facilitated the teacher in the learning process. This view was expressed by two teachers: 
"In my opinion, the learning objectives are not oriented to mastery of concepts in the material being taught but rather to the practice of the concept" (Teacher 3).

"In my opinion, this model makes it easy for teachers to implement it" (Teacher 2).

From the perspective of the teachers, the learning syntax of the religious ethical model was able to create an interactive and holistic learning atmosphere in the development of students' affective cognitive and psychomotor domains. This was stated by several teachers:

"Syntax in this learning can create interactive learning" (Teacher 1).

"Syntax in this learning can build learning that develops all student domains, including cognitive, affective, and psychomotor" (Teacher 4).

The instructional influence in the ethical religious learning model was able to develop prophetic characters in students, including siddiq, amanah, fathonah, and tabligh. This statement was expressed by several teachers:

"Based on my observations, after implementing this model, it shows a change in religious behavior when participating in further learning activities. Students tend to show an attitude of responsibility, think solution and increase student learning ethics and politeness in speaking" (Teacher 3 ).

"I think this model can develop students' prophetic character. This can be seen from the emergence of indicators in the character of siddiq, amanah, fathonah, and tabligh in the personality of students" (Teacher

4).

Thus, from the teachers' perspective, the religious ethical model had been able to answer the problems encountered by teachers in developing student character through PAI learning in the pandemic era.

\section{Discussion}

The aforementioned findings show that the religious ethical model has been able to develop the religious character of students through PAI subjects. The transformed values can build students' awareness of the nature of values, and form their attitudes in accordance with the objectives built in a learning model (Markes, 2020), in this case the religious ethical model. This model is a recommendation as well as an evaluation to measure the extent of teacher involvement in using learning strategies that reflect religious values as learning principles (Whittle \& McKinney, 2020). It is necessary for teachers to improve their professional and pedagogic competencies continually (Orchard, 2020). Teacher competence improvement is required so that teachers can carry out their duties competently and achieve success in teaching. According to Joyce et al. (2009), successful teachers are not just charismatic and persuasive presenters. They are those who involve students in cognitive and socially-oriented tasks and teach them how to perform the tasks effectively. Dialogic, constructivist, inquiry-based and aesthetic approaches need to be developed in learning activities so that the expected learning target can be achieved (Stern, 2021), which in the context of this research, is the development of students' religious character. 
The findings provide an understanding that for the success of a learning process, teachers need to innovate by developing learning models that are able to develop three domains, namely cognitive, affective and psychomotor, especially in developing character, in which the core of education is basically the development of moral values (Halstead \& Taylor, 1995). Innovation in learning is a necessity for teachers in developing styles of learning and teaching, particularly during online learning in the pandemic era (Mercer, 2021). They need to strive improve their ability to adapt to technological devices continually.

One of the causes of the teachers' failure in growing students' character is owing to the fact that teachers pay less attention to the affective aspect that is linked to the lack of pedagogic competence of teachers in teaching values, namely how teachers plan, implement and evaluate value learning. The learning paradigm used is more inclined to emphasize the head start aspect rather than the heart start. In Ratna (2009, p. 37), cases such as antisocial personality disorder and learning disability developed from a head start educational paradigm. Where there is a paradigm, the learning process carried out by teachers emphasizes hard skills rather than soft skills. Therefore, a reconstruction of education is needed in building a new paradigm of education (Barr \& Tagg, 1995; Savin-Baden \& Major, 2004; Tagg, 2003) which is an educational paradigm that not only focuses on changes in cognitive and psychomotor aspects but also on affective aspects. The main key to this paradigm growth must be in line with the teachers' motivation to be willing to innovate and change continually (McCulloch, 2013; Supriyadi et al., 2020).

Teachers' ability to enhance learning means that they must also possess literacy skills as evidenced by their ability to read studies that can expand their capabilities, such as how teacher learning is explored through the proposal or discussion of teacher professional learning models (Castle, 2006; James \& McCormick, 2009; Olson \& Craig, 2001). This is how teachers learn and change by developing or applying theory to the discussion of teacher development (Clarke \& Hollingsworth, 2002; Korthagen, 2010). Therefore, according to the results of this study, a teacher needs to practice the ADDIE development model in an effort to correct and improve the learning effort quality.

\section{Conclusion}

The promotion of religious ethical values are significant in the learning process in order to form students' morals or character because religion and morals cannot be separated; rather, they become an important part of the moral education process. With this consideration, teachers need to innovate by designing and developing learning methods in order to be able to cultivate religious ethical values in students. Through the method of knowing, doing, and being as the syntax in this learning, religious ethical values are inculcated so that students are able to exhibit good character and moral character performance. The standard of goodness is measured in four prophetic characters, namely, siddiq, amanah, fathonah and tabligh. The implementation of this model has been able to promote these four prophetic character attributes. Therefore, for further research that 
intends to develop an ethical religious character in the learning process, this model can be used as a reference or a compass in implementing learning based on prophetic character values. The results of this research contribute to the development of learning designs to improve students' prophetic character. The implications of this can ultimately contribute to the success of the PAI learning process and student achievement

\section{Acknowledgement}

The researchers express their deep gratitude to Universitas Islam Bandung, which has supported funding in this research, and the professors at Universitas Pendidikan Indonesia who have provided support and input in the implementation of this research. However, in this case, the researchers state that this research is free from conflicts of interest.

\section{References}

Abdo, M., \& Semela, T. (2010). Teachers of poor communities: The tale of instructional media use in primary schools of Gedeo Zone, Southern Ethiopiaj. Australian Journal of Teacher Education (Online), 35(7), 78-92. https://doi.org/10.3316/informit.818668041340479

Abdurrahman, M. (2005). Islam yang memihak. LKIS Pelangi Aksara.

Aini, W. N. (2013). Instructional media in teaching English to young learners: A case study in elementary schools in Kuningan. Journal of English and Education, 1(1), 196-205. https:/ / ejournal.upi.edu/index.php/L-E/article/view/350

Alawamleh, M., Al-Twait, L. M., \& Al-Saht, G. R. (2020). The effect of online learning on communication between instructors and students during Covid-19 pandemic. Asian Education and Development Studies. https://doi.org/10.1108/aeds-06-20200131

Albright, C. R., \& Ashbrook, J. B. (2001). Where God lives in the human brain. Sourcebooks.

Albulescu, I. (2019). Democratic Citizenship and Moral-Religious Values. Axiological Benchmarks in the Education for Democratic Citizenship. Educatia 21, 17, 5-13. https://doi.org/10.24193/ed21.2019.17.01

Ali, M. M. (2015). The living thoughts of the Prophet Muhammad. Ahmadiyya Anjuman Ishaat Islam Lahore USA.

Alim, N., Linda, W., Gunawan, F., \& Saad, M. S. M. (2019). The effectiveness of Google classroom as an instructional media: A case of state islamic institute of Kendari, Indonesia. Humanities $\mathcal{E}$ Social Sciences Reviews, 7(2), 240-246. https://doi.org/10.18510/hssr.2019.7227

Baloran, E. T. (2020). Knowledge, attitudes, anxiety, and coping strategies of students during COVID-19 pandemic. Journal of Loss and Trauma, 25(8), 635-642. https:/ / doi.org/10.1080/15325024.2020.1769300

Barr, R. B., \& Tagg, J. (1995). From Teaching to Learning-A New Paradigm For Undergraduate Education. Change: The Magazine of Higher Learning, 27(6), 12-26. https://doi.org/10.1080/00091383.1995.10544672

Basri, N. H., Maliki, Z., Iswati, S., Rofaida, R., \& Meidiaswati, H. (2020). The linkage of competence, professionalism and islamic work ethic: A literature review. Journal of Innovation in Business and Economics, 4(01), 31-38. https://doi.org/10.22219/jibe.v4i01.8409

Baturay, M. H. (2008). Characteristics of basic instructional design models. Ekev Academic Review, 12(34), 471-482.

Bertens, K. (1993). Etika K. Bertens (Vol. 21). Gramedia Pustaka Utama. 
Boonsong, S., Siharak, S., \& Srikanok, V. (2018). Development of Learning Management in Moral Ethics and Code of Ethics of the Teaching Profession Course. IOP Conference Series: Materials Science and Engineering, 306(1). https://doi.org/10.1088/1757899X/306/1/012113

Branch, R. M. (2009). Instructional design: The ADDIE approach (Vol. 722). Springer Science \& Business Media.

Budiyono, I., Hamidah, H., \& Yasin, M. (2019). The Effect of Prophetic Leadership on Employee Engagement At sufism-based Islamic Boarding School. Proceedings of the 1st International Conference on Business, Law And Pedagogy, ICBLP 2019. https://doi.org/10.4108/eai.13-2-2019.2287495

Burge, S. (2020). The Prophet Muhammad: Islam and the Divine Message. Bloomsbury Publishing.

Castle, K. (2006). Autonomy through pedagogical research. Teaching and Teacher Education, 22(8), 1094-1103. https://doi.org/10.1016/j.tate.2006.07.001

Cheung, L. (2016). Using the ADDIE model of instructional design to teach chest radiograph interpretation. Journal of Biomedical Education, 2016, 1-6. https://doi.org/10.1155/2016/9502572

Clarke, D., \& Hollingsworth, H. (2002). Elaborating a model of teacher professional growth. Teaching and Teacher Education, 18(8), 947-967. https:// doi.org/10.1016/S0742-051X(02)00053-7

Conrad, R. M., \& Donaldson, J. A. (2011). Engaging the online learner: Activities and resources for creative instruction (Vol. 38). John Wiley \& Sons.

DeBusk, M., \& Hellison, D. (1989). Implementing a physical education self-responsibility model for delinquency-prone youth. Journal of Teaching in Physical Education, 8(2), 104-112. https://doi.org/10.1123/jtpe.8.2.104

Dijkstra, S., Schott, F., Seel, N., Tennyson, R. D., \& Seel, N. M. (2013). Instructional Design: International Perspectives II: Volume I: Theory, Research, and Models: volume Ii: Solving Instructional Design Problems. Routledge. https://doi.org/10.4324/9781315044743

Duperon, M. (2018). Learning for oneself: A Confucian-inspired case for moral formation in ethics pedagogy. Teaching Theology and Religion, 21(1), 4-20. https://doi.org/10.1111/teth.12416

Emmons, R. A., \& Paloutzian, R. F. (2003). The psychology of religion. Annual Review of Psychology, 54(1), 377-402. https://doi.org/10.1146/annurev.psych.54.101601.145024

Figley, G. E. (1984). Moral education through physical education. Quest, 36(1), 89-101. https://doi.org/10.1080/00336297.1984.10483804

Fridayanti, F. (2015). Religiusitas, Spiritualitas Dalam Kajian Psikologi dan Urgensi Perumusan Religiusitas Islam. Psympathic: Jurnal Ilmiah Psikologi, 2(2), 199-208. https://doi.org/10.15575/psy.v2i2.460

Gagne, R. M., Wager, W. W., Golas, K. C., Keller, J. M., \& Russell, J. D. (2005). Principles of instructional design. Wiley Online Library.

Glasser, W. (1999). Choice theory: A new psychology of personal freedom. HarperPerennial.

Graham, G. (2011). Theories of Ethics An Introduction to Moral Philosophy with a Selection of Classic Readings. Routledge.

Halstead, J. M., \& Taylor, M. J. (1995). Values and values education in schools (1st ed.). Falmer Press, Taylor \& Francis. https:/ / doi.org/10.4324/9780203973554

Hsu, T. C., Lee-Hsieh, J., Turton, M. A., \& Cheng, S. F. (2014). Using the ADDIE model to develop online continuing education courses on caring for nurses in Taiwan. The Journal of Continuing Education in Nursing, 45(3), 124. https://doi.org/10.3928/00220124-20140219-04 
Intania, E. V. (2020). The role of character education in learning during the COVID-19 pandemic Peran pendidikan karakter dalam pembelajaran selama pandemi. Jurnal Penelitian Ilmu Pendidikan, 13(2), 129-136. https://doi.org/10.21831/jpipfip.v13i2.32979

Izutsu, T. (2006). Ethico-Religious Concepts in the Quran. McGill University Press.

James, M., \& McCormick, R. (2009). Teachers learning how to learn. Teaching and Teacher Education, 25(7), 973-982. https://doi.org/10.1016/j.tate.2009.02.023

Joyce, B., Marsha, W., \& Calhoun, E. (2009). Models of Teaching. EightEdition. Alyn and Bacon.

Kama Abdul Hakam. (2010). Model Pembelajaran Pendidikan Nilai. CV. Yasindo Multi Aspek.

Katz, M. H. (2010). The Prophet Muhammad in Ritual. I Brockopp, Jonathan E.(Red.): The Cambridge Companion to Muhammad. Cambridge, 139-157. https://doi.org/10.1017/ccol9780521886079.008

Khāan, V. (2009). The Prophet of Peace: Teachings of the Prophet Muhammad. Penguin Books India.

Ko, S., \& Rossen, S. (2017). Teaching online: A practical guide. Routledge. https://doi.org/10.4324/9780203427354

Korthagen, F. A. J. (2010). Situated learning theory and the pedagogy of teacher education: Towards an integrative view of teacher behavior and teacher learning. Teaching and Teacher Education, 26(1), 98-106. https://doi.org/10.1016/j.tate.2009.05.001

Krings, V. C., Steeden, B., Abrams, D., \& Hogg, M. A. (2021). Social attitudes and behavior in the COVID-19 pandemic: Evidence and prospects from research on group processes and intergroup relations. SAGE Publications Sage UK: London, England. https://doi.org/10.1177/1368430220986673

Lafleur, A., Babin, M., Michaud-Couture, C., Lacasse, M., Giguère, Y., Cantat, A., Allen, C., \& Gingras, N. (2021). Implementing competency-based education in multiple programs: A workshop to structure and monitor programs' priorities using ADDIE. The Journal of Competency-Based Education, April, 1-8. https://doi.org/10.1002/cbe2.1257

Lewis, C. A., \& Cruise, S. M. (2006). Religion and happiness: Consensus, contradictions, comments and concerns. Mental Health, Religion and Culture, 9(03), 213-225. https://doi.org/10.1080/13694670600615276

Licona, T. (1991). Educating for character: how our school can teach respect and responsibility. Bantambooks.

Markes, K. D. (2020). Living Values Education Dan Implikasinya Bagi Pendidikan Agama $\begin{array}{llll}\text { Kristen. Manna 220-240. } & \text { Rafflesia, }\end{array}$ https://doi.org/10.38091/man_raf.v6i2.120

McClain, K. (2002). Teacher's and students' understanding: The role of tools and inscriptions in supporting effective communication. Journal of the Learning Sciences, 11(2-3), 217-249. https:/ / doi.org/10.1080/10508406.2002.9672138

McCulloch, G. (2013). Educational reconstruction: The 1944 education act and the twenty-first century. Routledge.

Mercer, J. A. (2021). Reports from Religious Educators at Work amid the COVID-19 Global Pandemic (pp. 1-2). Taylor \& https://doi.org/10.1080/00344087.2021.1876607

Metzler, M. (2017). Instructional models in physical education (3rd ed.). Routledge. https:// doi.org/10.4324/9781315213521

Milliren, A., \& Messer, M. H. (2009). “ Invitations" To Character. Journal of Invitational Theory \& Practice, 15. 
Mouratidou, K., Goutza, S., \& Chatzopoulos, D. (2007). Physical education and moral development: An intervention programme to promote moral reasoning through physical education in high school students. European Physical Education Review, 13(1), 41-56. https://doi.org/10.1177/1356336X07072675

Muhtar, T., Supriyadi, T., Lengkana, A. S., \& Hanifah, S. (2020). Religious CharactersBased Physical Education Learning in Elementary School. International Journal of Learning, Teaching and Educational Research, 18(12). https://doi.org/10.26803/ijlter.18.12.13

Oh, E. G., Lee, H. J., Yang, Y. L., Lee, S., \& Kim, Y. M. (2021). Development of a discharge education program using the teach-back method for heart failure patients. BMC Nursing, 20(1), 1-9. https:// doi.org/10.1186/s12912-021-00622-2

Olson, M. R., \& Craig, C. J. (2001). Opportunities and challenges in the development of teachers' knowledge: The development of narrative authority through knowledge communities. Teaching and Teacher Education, 17(6), 667-684. https:// doi.org/10.1016/s0742-051x(01)00023-3

Orchard, J. (2020). Does RE still matter? Journal of Religious Education, 68(3), 271-287. https://doi.org/10.1007/s40839-020-00121-7

Peraturan Pemerintah, R. I. (2007). No. 55, Tahun 2007 Tentang Pendidikan Agama dan Pendidikan Keagamaan. Direktorat Jenderal Islam Departemen Agama RI.

Ratna, M. (2009). Pendidikan Karakter. Indonesia Heritage Foundation.

Rusman. (2011). Model-model pembelajaran: mengembangkan profesionalisme guru. Rajawali Pers/PT Raja Grafindo Persada.

Ryan, K., Bohlin, K. E., \& McDonnell, S. N. (1999). Building character in schools: Practical ways to bring moral instruction to life. Jossey-Bass San Francisco.

Saluun, P. M., \& Timin, L. A. (2020). Religious Ethical Values: A Sine Qua Non for a Developed Nigerian Nation. Saudi Journal of Humanities and Social Sciences, 05(01). https:// doi.org/10.36348\%2Fsjhss.2020.v05i01.003

Savin-Baden, M., \& Major, C. H. (2004). Foundations of problem-based learning. McGraw-Hill Education (UK).

Schoeler, G. (2010). The Biography of Muhammad: Nature and Authenticity. Routledge. https://doi.org/10.4324/9780203850060

Soto-Pérez, M., Ávila-Palet, J. E., \& Núñez-Ríos, J. E. (2021). Justice, Deontology and Moral Meaningfulness as Factors to Improve Student Performance and Academic Achievement. Journal of Academic Ethics, 0123456789. https://doi.org/10.1007/s10805-021-09423-3

Stern, J. (2021). persons, pedagogy, policy and philosophy (pp. 361-363). Taylor \& Francis. https://doi.org/10.1080/01416200.2021.1938423

Strunc, A. R. (2020). Are They Listening? Policymakers and Their Role in Public Education. Research in Educational Policy and Management, 2(1), i-iii. https:// doi.org/10.46303/repam.02.01.ed

Suherman, A., Supriyadi, T., \& Cukarso, S. H. I. (2019). Strengthening national character education through physical education: An action research in indonesia. International Journal of Learning, Teaching and Educational Research, 18(11). https:// doi.org/10.26803/ijlter.18.11.8

Suleymanova, D. (2020). Pedagogy of Islam: Madrasa Education and Moral Upbringing. In Pedagogies of Culture (pp. 151-172). Springer. https://doi.org/10.1007/978-3030-27245-6_5

Sultoni, A., Wasim, A. T., \& Fauzan, A. (2020). Development of Prophetic Intelligence (Phenomenology Study of Religious Transformation). International Journal of Islamic Educational Psychology, 1(1), 12-24. https://doi.org/10.18196/ijiep.1102 
Supriyadi, T, Julia, J., Iswara, P. D., \& Abdussalam, A. (2019). ICT-Based Al-Qur'an phonology learning. Journal of Physics: Conference Series, 1402, 77020. https://doi.org/10.1088/1742-6596/1402/7/077020

Supriyadi, Tedi, Julia, J., Aeni, A. N., \& Sumarna, E. (2020). Action Research in Hadith Literacy: A Reflection of Hadith Learning in the Digital Age. International Journal of Learning, Teaching and Educational Research, 19(5), 99-124. https://doi.org/10.26803/ijlter.19.5.6

Supriyadi, Tedi, Saptani, E., Rukmana, A., Suherman, A., Alif, M. N., \& Rahminawati, N. (2020). Students' Technological Literacy to Improve Academic Writing and Publication Quality. Universal Journal of Educational Research, 8(11B), 6022-6035. https://doi.org/10.13189/ujer.2020.082238

Suyitno, H. (2019). Integration of Character Values in Teaching-Learning Process of Mathematics at Elementary School of Japan. International Journal of Instruction, 12(3), 781-794. https://www.e-iji.net/dosyalar/iji_2019_3_47.pdf

Tagg, J. (2003). The learning paradigm college. Anker Publishing Company Bolton, MA.

Tayeb, T. (2017). Analisis dan Manfaat Model Pembelajaran. AULADUNA: Jurnal Pendidikan Dasar Islam, 4(2), 48-55. https://doi.org/10.24252/auladuna.v4i2a5.2017

Vanden Auweele, D. (2015). Kant on religious moral education. Kantian Review, 20(3), 373394. https://doi.org/10.1017/S136941541500014X

Wardhani, F. P. (2018). Student gadget addiction behavior in the perspective of respectful framework. Konselor, 7(3), 116-123. https://doi.org/10.24036/0201872100184-000

Whittle, S., \& McKinney, S. J. (2020). AULRE 2020: RE Matters. Journal of Religious Education, 68, 267-270. https://doi.org/10.1007/s40839-020-00123-5

Wong, M. M. L., Lau, K. H., \& Chan, C. W. F. (2021). The impacts and success factors of a work-from-home service-learning internship during COVID-19. Journal of WorkApplied Management. https:// doi.org/10.1108/JWAM-01-2021-0003

Wortham, S. C. (2006). Early childhood curriculum: Developmental bases for learning and teaching. Kevin M. http://digilib.umpalopo.ac.id:8080/jspui/handle/123456789/379\%0A

Yasin, M. (2020). The Role of Prophetic Leadership on Workplace Spirituality At sufismbased Islamic Boarding School. Journal of Business and Behavioural Entrepreneurship, 4(1), 122-129. https://doi.org/10.21009/JOBBE.004.1.09

Yu, J., \& Jee, Y. (2021). Analysis of online classes in physical education during the covid19 pandemic. Education Sciences, 11(1), 1-14. https://doi.org/10.3390/EDUCSCI11010003

Yu, S. J., Hsueh, Y. L., Sun, J. C. Y., \& Liu, H. Z. (2021). Developing an intelligent virtual reality interactive system based on the ADDIE model for learning pour-over coffee brewing. Computers and Education: Artificial Intelligence, 2, 100030. https://doi.org/10.1016/j.caeai.2021.100030

Yun-fei, Z. (2004). Reflection on Carrying out Club Model in Physical Education Teaching of Colleges and Universities. Journal-Shanghai Physical Education Institute, 28, 92 94. https://en.cnki.com.cn/Article_en/CJFDTotal-STYB200403022.html

Yusupova, G. (2020). The religious field in a Russian Muslim village: A Bourdieusian perspective on Islam. Ethnicities, 1468796820904208. https://doi.org/10.1177/1468796820904208 


\section{Appendix}

\section{Ethical Consideration}

This research has been approved by the institutional review board. All methods were carried out in accordance with relevant guidelines and regulations. In addition, this research obtained approval from the association of lecturers and character educators of Indonesia to conduct research. All participants were informed about the objectives, procedures, and possible benefits and risks of the research. Then, they were given time to consider their participation and voluntarily take part in the study. 